\title{
Analysis of the pharmaceutical care activities practiced by private homeopathic pharmacies located in Rio de Janeiro North Zone
}

\author{
Daniele Osorio Pacheco스, Tereza Cristina Andrade Leitão Aguiar 1,2
}

(1) Estácio de Sá University, Rio de Janeiro, Brazil

(2) Fluminense Federal University, Rio de Janeiro, Brazil,

\begin{abstract}
The complexity of homeopathic treatment delegates to the Pharmacist the need and the responsibility of pharmaceutical care. This paper had the objective of verifying the practices of pharmaceutical care in homeopathy. The study was conducted in homeopathic pharmacies situated in Rio de Janeiro North Zone, during March and April, 2011, where 15 pharmacists were interviewed, with the help of a semi-open questionary self-administered. For the survey were investigated variables related to pharmaceutical: sex, age, nature of the institution where he graduated, having completed post-graduate and working ties. Information professionals for the pharmaceutical care were collected in 14 questions grouped into three areas: attitudes, perceptions and satisfaction. Attending the ethical aspects, the study was submitted to and approved by the Ethics Committee of University Estácio de Sá. The results demonstrated that 33\% of the pharmacists have less than 5 years of professional practice, and $53 \%$ are specialists graduated by the Hahnemann's Institutite of Brasil. All Pharmacists claim to orient patients, mostly during dispensation and through phone contacts. Most pharmacists oriented patients passively and actively. The elderly were pointed as the ones, who most often sought orientation. During dispensation of homeopathic drugs, all patients elicit some orientation. $67 \%$ of the pharmacies keep material for pharmaceutical guidance to the patients, usually leaflets. The verbal and written orientation was predominanted on homeopathic pharmacist. Posology and instructions of use for the pharmaceutical form dispensed were described as the most common doubts of the patients. Of all pharmacists interviewed, $67 \%$ pointed to self-medication practices in the pharmacy. The questions which measure the position and perception of the pharmacists related to pharmaceutical assistance scored over 3. The question which scored higher was related to the patient trust regarding the pharmacist guidance. We concluded that there was a mobilization on the pharmacists side to overcome obstacles and focus on the patient through the practices of pharmaceutical care.
\end{abstract}

Keywords: Homeopathy, Pharmaceutical Care, Pharmaceutical Care in Homeopathy. 


\section{Análise das ações da atenção farmacêutica praticada pelas farmácias homeopáticas privadas localizadas na Zona Norte do município do Rio de Janeiro}

\section{RESUMO}

A complexidade existente no tratamento homeopático é o que remete ao farmacêutico a responsabilidade e a necessidade de ações de atenção farmacêutica. Este trabalho teve como objetivo verificar a prática de ações de atenção farmacêutica em homeopatia. O estudo foi realizado em farmácias homeopáticas situadas na Zona Norte do Rio de Janeiro no período de março a abril de 2011, onde 15 farmacêuticos foram entrevistados, com o auxílio de um questionário semi-aberto auto-aplicável. Para a pesquisa foram investigadas variáveis relativas aos farmacêuticos: sexo, idade, natureza da instituição em que graduou, ter cursado pós-graduação e vínculo de trabalho. As informações dos profissionais relativas à atenção farmacêutica foram coletadas em 14 perguntas agrupadas em três domínios: atitudes, percepção e satisfação. Atendendo aos aspectos éticos, o estudo foi submetido e aprovado pelo Comitê de Ética em Pesquisa da Universidade Estácio de Sá. Os resultados mostraram que 33\% dos farmacêuticos tem menos de 5 anos de experiência profissional e 53\% foram formados como especialistas em homeopatia pelo Instituto Hahnemaniano do Brasil. Todos os farmacêuticos afirmaram realizar orientação farmacêutica junto aos pacientes, principalmente durante a dispensação e pelo telefone. A maioria dos farmacêuticos orientaram os pacientes de forma ativa e passiva. Os idosos foram apontados como os que mais procuram orientação farmacêutica. Durante a dispensação do medicamento homeopático, todos os pacientes solicitaram alguma orientação. $67 \%$ das farmácias disponibilizam material para orientação farmacêutica ao paciente, sendo na maioria das vezes um folheto. A orientação escrita e verbal foi a predominante segundo os farmacêuticos entrevistados. A posologia e a maneira de administrar a forma farmacêutica dispensada foram descritas como as dúvidas mais freqüentes dos pacientes. Dos entrevistados 67\% referiram a prática de automedicação nas farmácias. As questões que medem atitude e percepção dos farmacêuticos com relação a atenção farmacêutica obtiveram escores acima de 3. A questão que apresentou o escore mais alto estava relacionada à confiança do paciente em relação às orientações do farmacêutico. Os farmacêuticos mostraram-se motivados a superar os empecilhos focando no paciente através das práticas de atenção farmacêutica.

Palavras-chave: Homeopatia; Atenção Farmacêutica; Atenção Farmacêutica em Homeopatia.

\section{(cc) BY-NC-ND Licensed to GIRI}

Support: authors declare that this study received no funding

Conflict of interest: authors declare there is no conflict of interest

Correspondence author: Tereza Leitão, terezaleitão@oi.com.br,

How to cite this article: Pacheco DO, Leitão TCAA. Analysis of the pharmaceutical care activities practiced by private homeopathic pharmacies located in Rio de Janeiro North Zone. Int J High Dilution Res [online]. 2011 [cited YYYY Month dd]; 10(36): 229-230. Proceedings of the XXV GIRI Symposium and VIII CBFH; 2011 Sep 04-07; Foz do Iguaçu (Brazil). GIRI and ABFH; 2011; Available from: http://www.feg.unesp.br/ ojs/index.php/ijhdr/article/view/515/538 